\title{
PATRIMÔNIO INQUIRIDO: POR UMA HISTÓRIA DE MEMÓRIAS SUBTERRÂNEAS NOS SERTÕES DE GOIÁS EM 1930
}

\author{
Paulo Brito do Prado*
}

\begin{abstract}
Resumo: A Igreja de Nossa do Rosário em Goiás sempre nos intrigou, primeiro por sabermos que seu nome trazia silêncios e segundo porque havia sido demolida e reconstruída na década de 1930. Apegados a estes problemas partimos em busca de maiores esclarecimentos quanto a estas memórias subterrâneas, então nos deparamos com possíveis eliminações de memórias afro descendentes da história de Goiás. A anterior Igreja de Nossa Senhora do Rosário dos Pretos, feita por negros escravos para abrigar a irmandade em devoção à Nossa Senhora do Rosário dos Homens Pretos foi demolida por ordem dos dominicanos e, em seu lugar foi reconstruída outra igreja em um estilo europeu totalmente díspar das características arquitetônicas encontradas nos Sertões de Goiás, com a ajuda financeira da prefeitura e do povo vilaboense ${ }^{1}$, prática capaz de orientar problemas quanto à perspectiva patrimonial da cidade, o preconceito de raça e o direito à memória. Nos itinerários da pesquisa lançamos horizontes de expectativas alicerçados nos conceitos de memória, patrimônio, poder e identidade trabalhada por autores canônicos, com produção importante no campo das propostas aqui exercitadas.
\end{abstract}

Palavra Chave: Identidade. Memórias. Patrimônio. Goiás.

Abstract: The Church of Ours of Rosário in Goiás always intrigued us, first for we know that his/her name brought silences and second because it had been demolished and rebuilt in the decade of 1930. Attached the these problems left in search of larger explanations as for these underground memoirs, then we came across possible eliminations of memoirs descending afro of the history of Goiás. The previous Church of Ours Mrs. of Rosário of the Blacks, done by slave blacks to shelter the fraternity in devotion to Ours Mrs. of Rosário of the Black Men it was demolished by order of the Dominicans and, in his/her place other church was rebuilt in an European style totally disparate of the architectural characteristics found in the Interiors of Goiás, with the financial help of the city hall and of the people vilaboense, practice capable to guide problems as for the patrimonial perspective of the city, the race prejudice and the right to the memory. In the itineraries of the research we threw horizons of expectations found in the concepts of memory, patrimony, to can and identity worked by canonical authors, with important production in the field of the proposals here exercised.

Keywords: Identity. Memoires. Patrimony. Goiás.

\footnotetext{
* Mestre em História pela Universidade Federal de Goiás (UFG-GO), Professor da Secretaria de Educação do Estado de Goiás.

${ }^{1}$ Termo utilizado para se referir aos moradores nascidos na cidade de Goiás.
} 


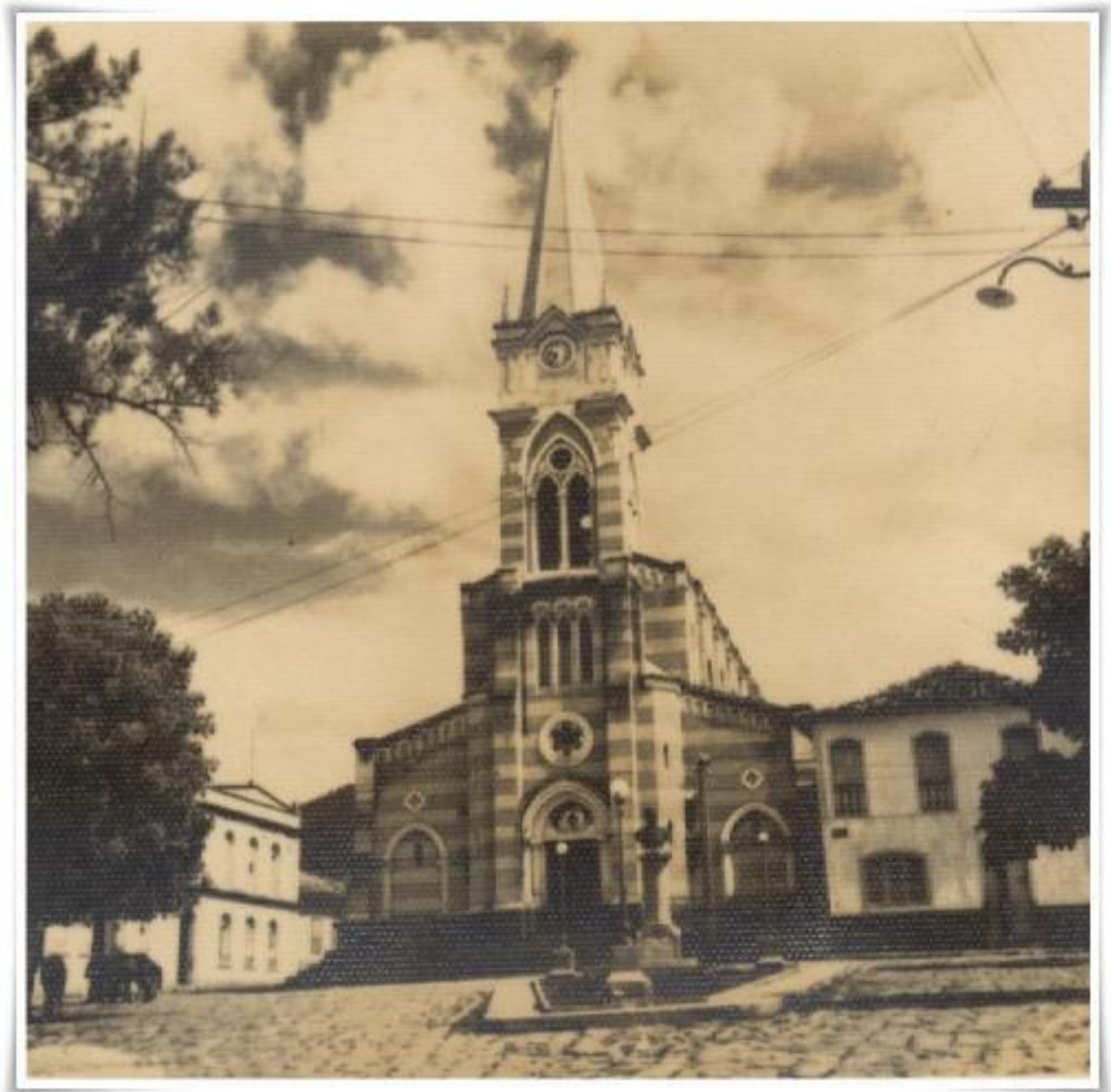

Fig. 01: Igreja de Nossa Senhora do Rosário em estilo neo gótico na década de 1950. Arquivo de Elder Camargo de Passos.

O trabalho propõe um debate reunindo a problematização de conceitos, tais como o patrimônio cultural, a identidade, a memória e o poder na cidade de Goiás, a partir da demolição da Igreja de Nossa do Rosário dos Pretos na década de 1930, e do recalque da cultura afro descendente na cidade.

Os indícios e as lembranças da anterior Igreja de Nossa Senhora do Rosário dos Pretos em Goiás, sempre nos atraiu a atenção, não apenas pela supressão da terminação "Pretos", mas pela transformação arquitetônica do prédio religioso após sua reedificação em 1930. Conforme conferido na petição número 696 feita pelo Frei Alberto M. Bartolan à prefeitura de Goiás, solicitando ajuda financeira para concluir a torre de uma igreja que representaria a “chegada da modernidade” à cidade, nas fotografias apropriadas graças à pesquisa em acervos 
particulares e públicos e no termo de compromisso da Irmandade de Nossa Senhora do Rosário dos Homens Pretos, na condição de "inquisidores" questionamos todas as fontes reunidas, na busca de uma síntese possível para alguns dos problemas elegidos e, tentamos lançar mão de esclarecimentos possíveis para a demolição da capela em estilo colonial, e a construção de uma nova com características dessemelhantes do conjunto arquitetônico regional.

Sua reconstrução em estilo neo-gótico a partir de 1932 representou o silêncio de memórias, identidades, cultos, festas e das lembranças da Irmandade negra, em ameaça de se extinguir a partir de 1883, como esclarecido por Gallais (1942, p. 71 - 72) em seus testemunhos:

\begin{abstract}
Quando os primeiros missionários chegaram a Goiás, em 1883, a Irmandade dos Negros ainda existia, mas em grande decadência. Havia muito que as minas da Califórnia, da Austrália, do sul da África, exploradas com todos os aperfeiçoamentos que a ciência, excitada pela cobiça, pudera inventar, causaram o abandono das do Brasil, sobretudo as de Goiás. Só se falava delas como de um fato histórico muito afastado no tempo. Por outro lado, em virtude de certas disposições legislativas proclamando a extinção progressiva da escravidão, o número de escravos havia diminuído muito. Efectivamente, a igreja do Rosário estava quase vacante e, esperando que o seu sucessor, D. Duarte Silva, suprimisse pura e simplesmente a Irmandade dos Negros, D. Gonsalves entendeu entregar sua igreja aos missionários. Tomaram estes posse dela, ao mesmo tempo que de uma casa que lhe ficava contígua. (GALLAIS, 1942, p. $71-72$ ).
\end{abstract}

Nos itinerários metodológicos e na busca de fontes que proporcionassem corroborar as propostas da pesquisa, foram realizadas perguntas com o intuito de ampliar os horizontes da escrita, do ensino da história regional, e de cotejar teoricamente a participação negra na construção das identidades culturais nos Sertões de Goiás. Verificou-se que o espaço ${ }^{2}$ ocupado pela igreja atual era antes o lugar de uma capela em estilo colonial construída com a finalidade de abrigar o culto a Nossa Senhora do Rosário dos Homens Pretos, trazido para o

\footnotetext{
${ }^{2}$ A categoria "espaço" assumiu no decorrer de nossos itinerários acepções distintas. Neste momento o utilizamos para nos referir ao lugar habitado e transformado pela ação humana. Seria ele "o fato histórico que ele é, vez que só a história da sociedade mundial, aliada à da sociedade local, pode servir como fundamento à compreensão da realidade espacial e permitir a sua transformação a serviço do homem" (SANTOS, 1977, p. 81). Através das concepções de Milton Santos compreendemos não ser possível escrever a história "fora do espaço, pois não há sociedade a - espacial. O espaço, ele mesmo, é social.” (1977, p. 81). Foi compreendendo o espaço como fruto das relações humanas que propomos analisar o lugar partindo de problemáticas patrimoniais e raciais, que cruzassem os significados de espaço-lugar e espaço-tempo. Utilizamos estas concepções de espaço, pois acreditamos ser o espaço - lugar fruto das intervenções humanas e o resultado de (re) significações construídas ao longo de anos (o espaço - tempo) desta forma entendemos ser este espaço - lugar - tempo um ambiente capaz de incorporar memórias, silêncios, esquecimentos, recalques e violências simbólicas. Cf. BOSI, 2003, 2004; HALBWACHS, 2006 e NORA, 1993.
} 
Brasil a partir da colonização portuguesa e do tráfico de negros pelo atlântico ${ }^{3}$, e institucionalizado a partir da criação de irmandades negras, visíveis graças à preservação dos manuscritos de compromissos, como no caso do termo de compromisso da Irmandade de Nossa Senhora do Rosário dos Homens Pretos que corrobora a presença de confrarias e irmandades religiosas em Goiás, e que neste momento se apresenta como parte fundamental para a construção deste roteiro de reminiscências.

Compromisso da Irmandade de Nossa Senhora do Rozário erecta na Villa Boa de Goyazes vai numerado, e por mim rubricado na conformidade das Reais Ordens e tem as folhas que constão do seu inserramento. Rio de Janeiro 14 de novembro de 1811. Nesta Irmandade não haverá número certo de Irmaons e Irmans, por que na mesma se aceitarão para mais prompto serviço, honra e louvor de Nossa Senhora do Rozário, todas as pessoas pretas, e de qualquer condição e qualidade, que nella se quizerem assentar por Irmoans, tanto de hum sexo como de outro assim cazados, como solteiros todas as vezes que tiverem doze annos de idade, e dahi para sima para o que o vos crie das Irmandades junto com o Thezoureiro $e$ Procurador farão os assentos no Livro delles recebendo primeiro a esmola de duas oitavas de entrada, declarando-lhe que cada hum apresentarão na primeira meza para se fazer carga no Livro de entrada e sahida do cofre. E da mesma forma o praticarão com as pessoas que quizerem se remidas, pagando dezaseis oitavas por huma só vez, sendo preto o que se remir não ficará izento dos cargos para que foi eleito ${ }^{4}$.

Diante de tantos dados e informações começamos a nos perguntar a respeito da problemática patrimonial na qual acabamos por envolver a demolição da antiga igreja, o recalque da memória da irmandade negra, o esquecimento de festejos agradáveis à escrita de uma história insuflada e capaz de apresentar um discurso interessado que nasceu de "lutas políticas, de embates de poder, e presidido por estratégias e táticas” (ALBUQUERQUE JUNIOR, 2007, p. 135) e que "portanto, não é um discurso imune à ideologia, mas plenamente ideológico" (2007, p.135).

Inspirados pelo saber transubstanciado de Albuquerque Junior (2007) aproveitamos o momento para questionar a inexistência, em Goiás, de estudos acerca da Entrada da Rainha ${ }^{5}$ e/ou da Congada $^{6}$, talvez porque acreditamos na adequação destas interrogações para a construção de maiores legitimidades para o trabalho aqui arrolado. A partir do mapeamento de fontes e na sua seleção, imaginamos caminhos e possibilidades para problematizar os

\footnotetext{
${ }^{3}$ Cf. KARASCH, 2010; LOIOLA, 2009 e MORAES, 2005.

${ }^{4}$ Cf. ALMEIDA, 2001. Termo de Compromisso da Irmandade de Nossa Senhora do Rosário dos Pretos p. 02 e 06.

${ }^{5}$ Cf. CURADO, 1989.

${ }^{6}$ Cf. LACERDA, 1977.
} 
possíveis silêncios, principalmente quando os relacionamos à ausência de lugares de memória evocados no trabalho por meio da demolição da Capela de Nossa Senhora do Rosário dos Pretos "erecta por Antonio Pereira Bahia em 1734, por provisão do Sr. D. Fr. Antonio de Guadalupe" (TELES, 1998, p. 111), e "substituída pela igreja de Nossa Senhora do Rosário, construída pelos Dominicanos franceses" (KARASCH, 2010, p. 265), em meados da década de 1930 em um estilo europeu, muito distante do padrão arquitetônico colonial esculpido por mãos negras e escravas em uma Goiás do antanho. Tratando-se de problemas, nos veio um amplo rol de perguntas umbilicalmente conectadas à demolição da igreja, aos silêncios quanto à questão racial em Goiás e ao apagamento de rastros da cultura negra na região. Compreendemos que as perguntas eram muitas e que não conseguiríamos respondê-las, então ao ampliarmos os horizontes de expectativas por meio das pesquisas documentais, encaramos as propostas como condições para se avaliar a problemática racial e identitária relacionandoas aos rastros patrimoniais ainda preservados na cidade e, lançamos conjecturas para a construção futura de esclarecimentos para os vazios historiográficos de Vila Boa de Goiás.

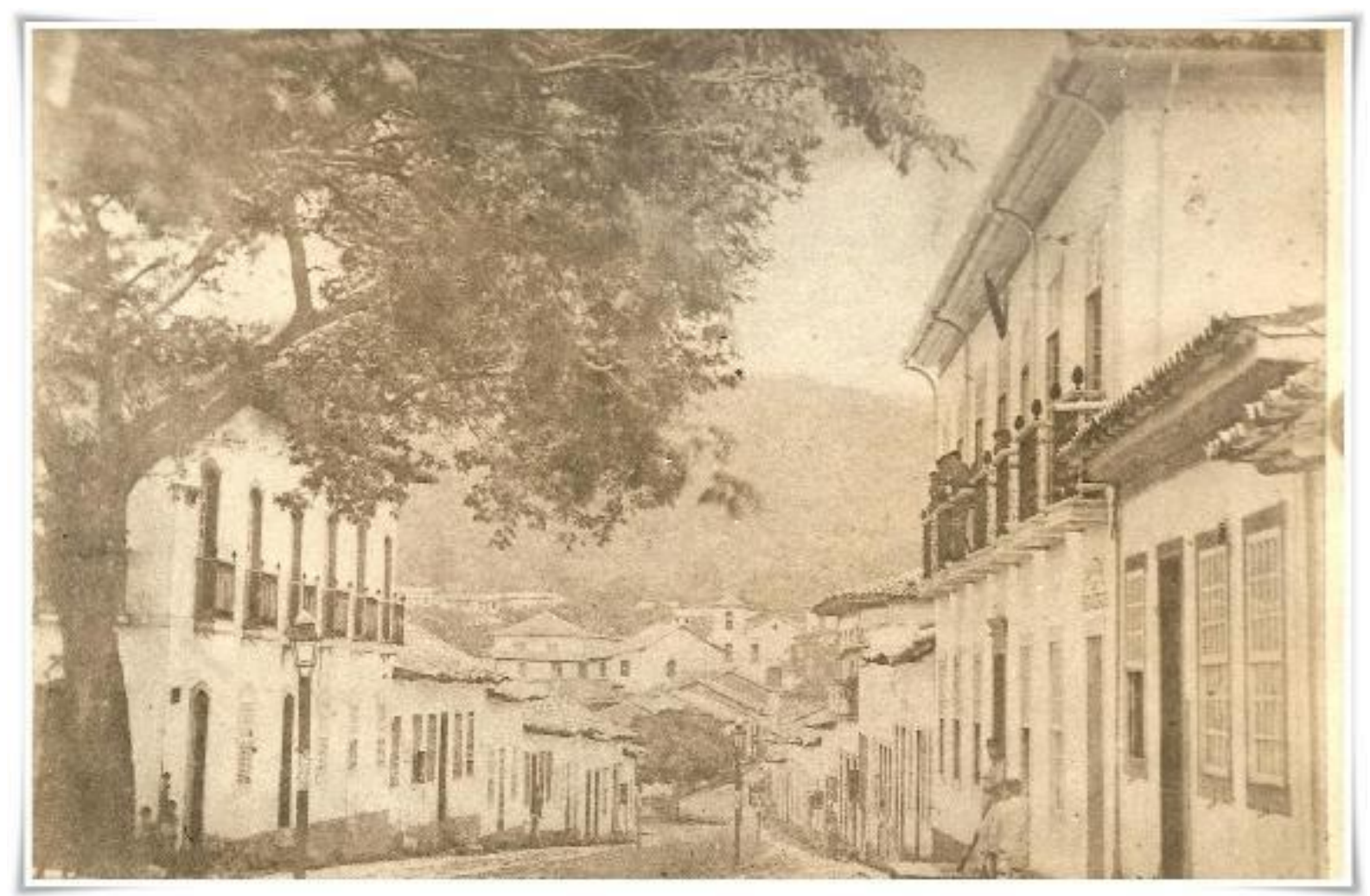

Fig. 02: Rua Moretti Foggia (Antiga Rua Direta, 1815). Década de 1930. Arquivo de Elder Camargo de Passos. 
Elaboramos então, um "diário de bordo" 7 e partimos em busca de testemunhos capazes de nos permitir a prática da desconstrução. Confrontamo-nos com vozes interessadas em “corromper as memórias dos poderosos" (Cf. ALBUQUERQUE JUNIOR, 2007), e assim lançar mão de novos esclarecimentos para o passado. Encontramos evidências, frutos "das perguntas que se fazem ao documento e ao fato de que, ao serem problematizados pelo historiador, transformam-se, em larga medida, em sua criação" (ALBUQUERQUE JUNIOR, 2007, p. 63) e finalmente no desenrolar da trama nos atinamos quanto à impossibilidade de considerar as fontes apenas como reflexos da realidade, ignorando todo e qualquer tipo de interpretação, e novamente retornamos a Albuquerque Junior (2007, p. 53-54), na busca de maiores ensinamentos:

Os objetos e as marcas deixadas pelo passado não traziam em si mesmos seu sentido, o passado não era o documento, nem os vestígios por ele deixados, mas a compreensão da trama histórica em que estavam envolvidos, só possível com um saber histórico e uma erudição previamente adquirida. (ALBUQURQUE JUNIOR, 2007, p. 53-54).

Ao combinarmos fontes, espaços de experiências, horizontes de expectativas e o patrimônio, nos deixamos conduzir pelos apontamentos de Choay (2001) e Jeudy (1990) e alicerçamos o trabalho às possibilidades de se extravasar o sentido patrimonial, ou da criação de monumentos, até porque, como sugerido por Le Goff (1990), os documentos utilizados nesta empreitada são monumentos que se combinam às necessidades de esclarecimentos para o passado e que se fazem prática recorrente nos trabalhos de Gagnebin (2001).

O patrimônio estava inicialmente ligado "às estruturas familiares, econômicas e jurídicas de uma sociedade estável, enraizada no espaço e no tempo" (CHOAY, 2001, p. 11), mas que por meio de ampliados debates sofreu um alargamento, transformando-se em representação, caracterizador de identidades e lugar capaz de aguçar a curiosidade por memórias, conforme sugerido por Nora (1993, p. 07):

A curiosidade pelos lugares onde a memória se cristaliza e se refugia está ligada a este momento particular da nossa história. Momento de articulação onde a consciência da ruptura com o passado se confunde com o sentimento de uma memória esfacelada, mas onde o esfacelamento desperta ainda memória suficiente para que se possa colocar o problema de sua encarnação. O sentimento de continuidade torna-se residual aos locais. Há

\footnotetext{
${ }^{7}$ A referência ao "diário de bordo" feita no texto serviu para evidenciar a construção de uma rede de relações e espaços de pesquisas produzidos antes da narração da trama aqui desenrolada.
} 
locais de memória porque não há mais meios de memória. (NORA, 1993, p. 07).

No ensaio Entre memória e história - a problemática dos lugares, Pierre Nora (1993) propôs uma abordagem bastante ampla acerca da memória, tendo como ponto de partida os lugares. Segundo suas concepções os lugares de memória nascem e vivem do sentimento que não há “memória espontânea, que é preciso criar arquivos, que é preciso manter aniversários, organizar celebrações, pronunciar elogios fúnebres, notariar atas, porque operações não são naturais" (NORA, 1993, p. 13), então apegados a esta concepção observamos não só o lugar de memória, mas a ausência deste lugar de memória, encarado como signo da ação do campo de poder e controle presentes em Goiás e, capazes de manipular datas, acontecimentos, lembranças e a própria história, como conferido por Bourdieu (1990, p. 24) ao se referir à temática:

Campo de forças possiveis, que se exercem sobre todos os corpos que nele podem entrar, o campo do poder é também um campo de lutas, e talvez, a esse titulo, comparado a um jogo: as disposições, ou seja, o conjunto das propriedades incorporadas, inclusive a elegância, a naturalidade ou mesmo a beleza, e o capital sob suas diversas formas, econômica, cultural, social, constituem trunfos que vão comandar a maneira de jogar e o sucesso no jogo, em suma, todo o processo de envelhecimento social que Flaubert chama de "educação sentimental". (BOURDIEU, 1990, p. 24).

A grande preocupação com o patrimônio cultural de Goiás nos fez problematizar o apagamento de lembranças, a ausência de memórias e representações da participação negra no rol da construção das identidades culturais nos Sertões de Goiás. Conforme sugerido por Hall (2006) a "identidade plenamente unificada, completa, segura e coerente é uma fantasia" (2006, p. 13), uma idealização, uma construção necessária de ser problematizada, por trazer em seu projeto silêncios e jogos presentes no campo do poder. Categoria que em sua vez é caracterizada por apostas e evidentemente domínios, de que é preciso conquistar ou conservar, e aqueles que "nele entram podem diferir sob dois aspectos: em primeiro lugar, do ponto de vista da herança, ou seja, dos trunfos; em segundo lugar, do ponto de vista da disposição do herdeiro ao seu respeito, ou seja, da 'vontade de vencer'” (BOURDIEU, 1900, p. 24 - 25) e de controlar, como no caso particular de Goiás, em que observamos uma política eficaz de exclusão e eliminação da memória das comunidades afro descendentes da participação na construção das identidades culturais por meio de uma herança patrimonial 
atraiçoada, pouco confiável e de uma memória histórica marcada pela construção da segregação negra, conforme sugerido por Coelho (1997, p. 93):

É durante esse período que a região escolhida anteriormente para a implantação da capela ocupada pela construção de residências com caráter mais permanente que aquelas encontradas no período anterior. Do outro lado do rio, também em local mais alto que aquele ocupado pela mineração, vai ser construída, ainda nesse período, a igreja de Nossa Senhora do Rosário, da irmandade dos pretos, inaugurando-se aí, da mesma forma como já havia acontecido em Minas Gerais, a segregação social e racial, com a utilização da primeira dessas edificações pelos brancos e senhores que já se estabeleciam em seu entorno, e a segunda pelos negros e pardos, que compunham a grande maioria dos habitantes da rua da Cambaúba, atual Bartolomeu Bueno. Aqui é bom observar que essas duas construções religiosas, situadas uma de cada lado do rio, cada uma com sua praça (ou largo, como era o termo utilizado à época), de certa forma concentraram ou centralizaram a ocupação do espaço urbano. (COELHO, 1997, p. 93).

Vale lembrar que além da política de exclusão social e racial adotada em Goiás desde sua organização arquitetônica, a partir do século XVIII, também foi verificado que no século XIX, o movimento de romanização promoveu grandes alterações na crença e no culto católico brasileiro $^{8}$. Em Goiás, conforme apresentado por Gallais (1942) a tomada da Igreja de Nossa Senhora do Rosário dos Pretos pelos dominicanos significou o início da romanização e transformação da crença católica popular na cidade. Assumimos esta problemática como uma oportunidade para questionarmos "os sistemas de significação e representação cultural, (...) uma multiplicidade desconcertante e cambiante de identidades possíveis (HALL, 2006, p. 13). A demolição da Igreja de Nossa Senhora do Rosário dos Pretos e a ereção de outra igreja em um estilo europeu reconhecido por neo-gótico ${ }^{9}$, fruto de uma corrente revivalista que tinha por objetivo "relembrar e reafirmar a grandeza de seus antigos colonizadores, e em paralelo, renovar o prestígio da colônia portuguesa para os aqui residentes" (MAIOLINO, 2007, p. 21) possuía motivações quanto à retomada das forças utilizadas no passado. "A primeira, de

\footnotetext{
${ }^{8}$ Cf. SILVA, 2005. "As festas populares sofreram diversas mudanças a partir da segunda metade do século XIX, em função da nova relação da Igreja Católica com a sociedade brasileira. Essa nova relação teve como principais elementos o fortalecimento de uma Igreja ultramontana e conservadora e a separação entre ela e o Estado, no final do século XIX, o que resultou em novos posicionamentos e práticas por parte da Igreja”. (SILVA, 2001, p. 57).

${ }^{9}$ Cf. MAIOLINO, 2007. "O neogótico ganhou força baseado em três problemáticas, que justificaram a adoção do estilo na arquitetura mais apropriada ao cristianismo: A oportunidade de impedir alterações e intervenções erradas nas grandes catedrais góticas. Violet Le Duc, na França e John Ruskin e Welby N. Pugin na Inglaterra, entre outros, sustentam no gótico uma arquitetura que valoriza a religiosidade em seu papel institucional e aparelhamento litúrgico, depois de séculos de laicismo anglicano nos edifícios religiosos. Relançar um estilo nacional inglês, contrapondo-se às academias francesas. / DIAS, Pollyanna D’Ávila G. O século XIX e o neogótico na arquitetura brasileira: um estudo de caracterização. In: Revista Ohun, 2008.
} 
motivação ideológica, política social, religiosa e nacionalista e a segunda, de criar uma nova arquitetura sincera e prática de acordo com a modernidade. (MAIOLINO, 2007, p. 17), e que permitiria a retomada de poder por parte da igreja católica, apagando assim qualquer traço da cultura negra que outrora existiu e se representou em determinados espaços de Vila Boa de Goiás.

Conforme corroborado pelos documentos e imagens anexadas, o modismo e a necessidade de representar a modernidade na arquitetura urbana não foi apenas uma característica de Paris, como citado por Choay (2001), ou do Rio de Janeiro, como conferido por José Murilo de Carvalho (1987), mas no interior do Brasil esta prática se fez presente. Vale a pena destacar no debate a eliminação de reminiscências importantes à história de Goiás, mesmo não havendo ainda nenhuma consciência de preservação patrimonial, pelo fato de o Serviço do Patrimônio Histórico e Artístico Nacional (SPHAN) ${ }^{10}$, ou o futuro Instituto do Patrimônio Histórico e Artístico Nacional (IPHAN) só aparecer no cenário brasileiro em fins de 1937, anos após a demolição da Capela de Nossa Senhora do Rosário dos Pretos, no entanto cabem nestes itinerários as seguintes perguntas: Porque demolir ícones e testemunhos da presença negra em Goiás, como a Igreja de Nossa Senhora do Rosário dos Pretos e o Pelourinho, guardiões da memória afro descendente nesta região, sendo que os documentos anexados anunciam a necessidade da modernidade e beleza em Vila Boa na década de 1930? A memória da presença negra em um lugar central da cidade seria algo incômodo?

A cidade guarda em sua imagem marcas de vários momentos diferentes de luta: as “teimosas marcas inscritas nas pedras das calçadas, os monumentos erguidos aos sucessivos vencedores, ou seja, marcas do passado que recebem significados diversos no transcorrer do tempo". (GIOVANAZ, 2007, p. 236).

A cidade é como um retábulo no qual são projetadas as memórias e reminiscências de um período distante. É o espaço que "recebe as marcas dos indivíduos que nele transitam" (GIOVANAZ, 2007, p. 237) e transitaram, portanto é um espaço "portador dos traços da história (ou do aniquilamento desses traços)" (BELLAIGUE, 2009, p. 88), cotidianamente “atravessado por interesses políticos diversos, por disputas de memória e poder". (CHAGAS, 2007, p. 220). Nesse ambiente de disputas e encerrado pelo campo do poder, verificamos por meio da análise de imagens e fotografias, maiores possibilidades para o trato da problemática patrimonial nos Sertões de Goiás.

${ }^{10}$ Cf. RUBINO, 1992. 
"Qualquer fotografia, não importa se aspire ou não ao status de arte, tem uma estética não aparente”. (SAMUEL, 2000, p. 25). Em prospecto de 1751, a cidade de Goiás se anuncia ainda como vila que posteriormente veio a se tornar uma importante cidade monumento, testemunha e guardiã das inspirações de Mnemósine e Clio. Localizado ao centro do prospecto, observamos a representação da Capela de Nossa Senhora do Rosário dos Pretos, destacada graças à sua arquitetura colonial entre uma diversidade de casarios que cochicham entre si. A inserção de imagens e/ou fotografias enquanto fonte indispensável para a escritura da trama se tornou importante signo capaz de compor estes itinerários pelo fato de estarem carregadas de um potencial cognitivo necessário para "compreendermos como ela tem sido explorada não só pela História, mas pelas ciências sociais (...)”. (MENESES, 2003, p. 12). Tratando-se de discussões acerca da problemática patrimonial principalmente quando nos defrontamos com silêncios, apagamentos e ausências de lugares de memórias, as imagens encaradas como registros do passado transformaram-se em monumentos capazes de promover o exercício de reivindicação da memória e identidade negra na região. A cidade de Goiás foi e é revestida por uma complexa relação de forças, percebida tanto por parte de seus emancipadores, como também pelas figuras simples que se fizeram presente nas ruas e casarios seculares. A Igreja de Nossa Senhora do Rosário dos Pretos vista da antiga Rua Direita, assim reconhecida em 1815, mas, todavia chamada em nossa imediatez cotidiana de Moretti Foggia, se confunde em uma paisagem capaz de aprisionar o espírito do tempo em suas pedras, janelas e telhados, à simplista arquitetura colonial, conforme esclareceu Gustavo Neiva Coelho (1997, p. 116):

Sendo assim, não somente os edifícios religiosos, mas praticamente todos os aspectos da arquitetura vão se apresentar revestidos de extrema simplicidade e sem qualquer sentido de erudição, ou de expressão plástica mais elaborada. A proibição, por parte da Coroa portuguesa, de estabelecimento de ordens religiosas em regiões mineradoras contribuiu grandemente para que os templos construídos no interior da colônia não apresentassem qualquer das orientações encontradas naqueles edifícios construídos no litoral. Passava-se, assim, a responsabilidade tanto da edificação quanto da manutenção para as mãos dos fiéis que, com total despreparo técnico e desprovidos de um mínimo de formação artística, simplesmente reproduziam aí um tipo de arquitetura representativa de seus antepassados culturais, tanto no nível do programa de necessidades quanto no de seleção e uso de materiais e técnicas construtivas. Essa desvinculação em relação às ordens religiosas vai promover o surgimento de uma certa liberdade construtiva, que no entanto se apresenta apenas relativa, já que, na ausência das ordens, o controle era assumido pelas confrarias e irmandades, que definiam, através de suas mesas diretoras, determinadas linhas e preceitos a serem seguidos. Mas, mesmo assim, com as irmandades o vocabulário formal dessas edificações se apresenta sempre com maior 
liberdade do que se estivesse sob orientação de uma ordem. (...) Aqui é bom observar que, mesmo sendo a capital, Vila Boa não vai apresentar grande diferença em sua arquitetura religiosa em relação ao restante da capitania. (COELHO, 1997, p. 116).

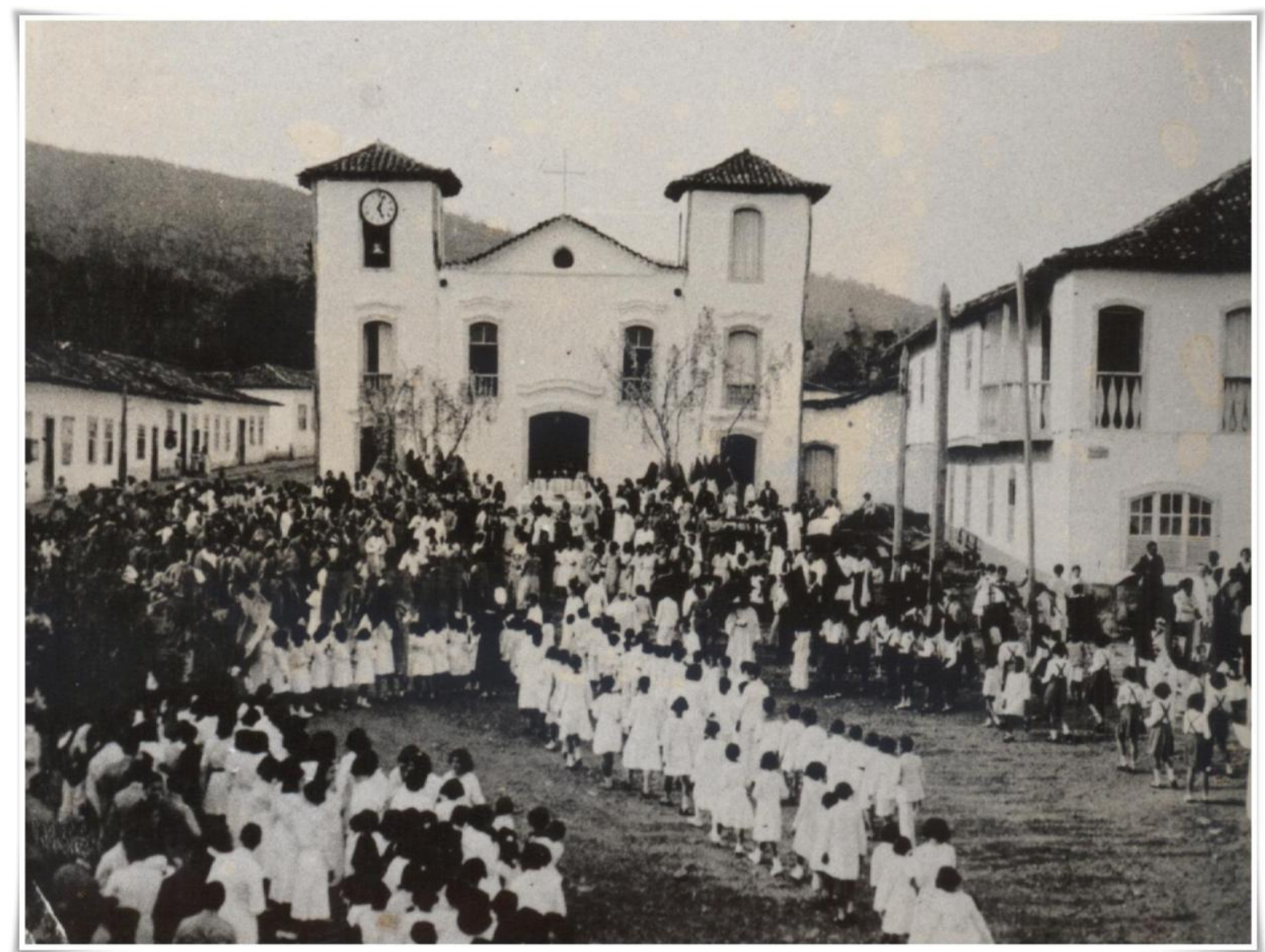

Fig. 03: Largo e Igreja de Nossa Senhora do Rosário dos Pretos em dia de comemoração religiosa. Arquivo de Elder Camargo de Passos.

As imagens, nesse caso "as fotos antigas não são exatamente memórias vivas, criam um espaço aleatório, e, fazendo uso da imaginação, levam-nos até eles”. (SAMUEL, 2000, p. 20). As conjecturas e perguntas acerca da cultura histórica em Goiás nos inquietaram quanto aos "objetos familiares e os lugares freqüentados pela comunidade que dialogam 'proustianamente' com seus membros, impondo indiscutivelmente o espaço como a 'realidade dura' e a sua materialidade objetal como prova inegável da passagem do grupo no tempo". (ELHAJII, 2010, p. 05). 


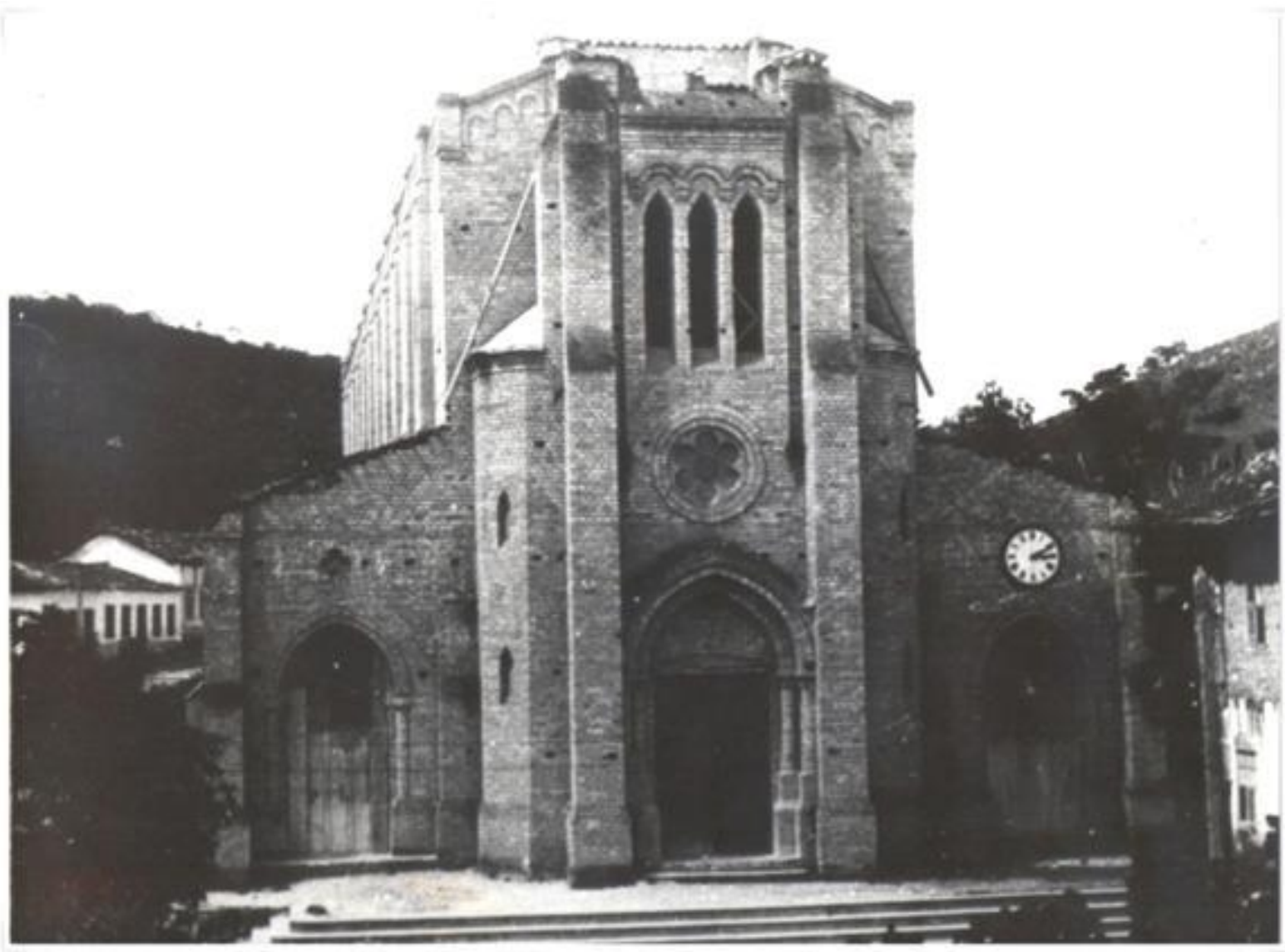

Fig. 04: Igreja de Nossa Senhora do Rosário em 1940. Arquivo de Elder Camargo de Passos.

Queríamos entender quais as causas da demolição da antiga igreja e o porquê de sua reconstrução em um estilo díspar da costumeira arquitetura colonial que se pode encontrar em todo o território goiano caracterizado por um "conjunto de edifícios religiosos extremamente simples, com características que de forma alguma se vinculam aos elementos decorativos e estéticos que definem formal e plasticamente os edifícios próprios das ordens religiosas estabelecidas no litoral da colônia". (COELHO, 1997, p. 116). Então no encalço de testemunhos e indícios, tropeçamos em documentos capazes de corroborar as perguntas lançadas na pesquisa por meio da escrita de tempos perdidos. 


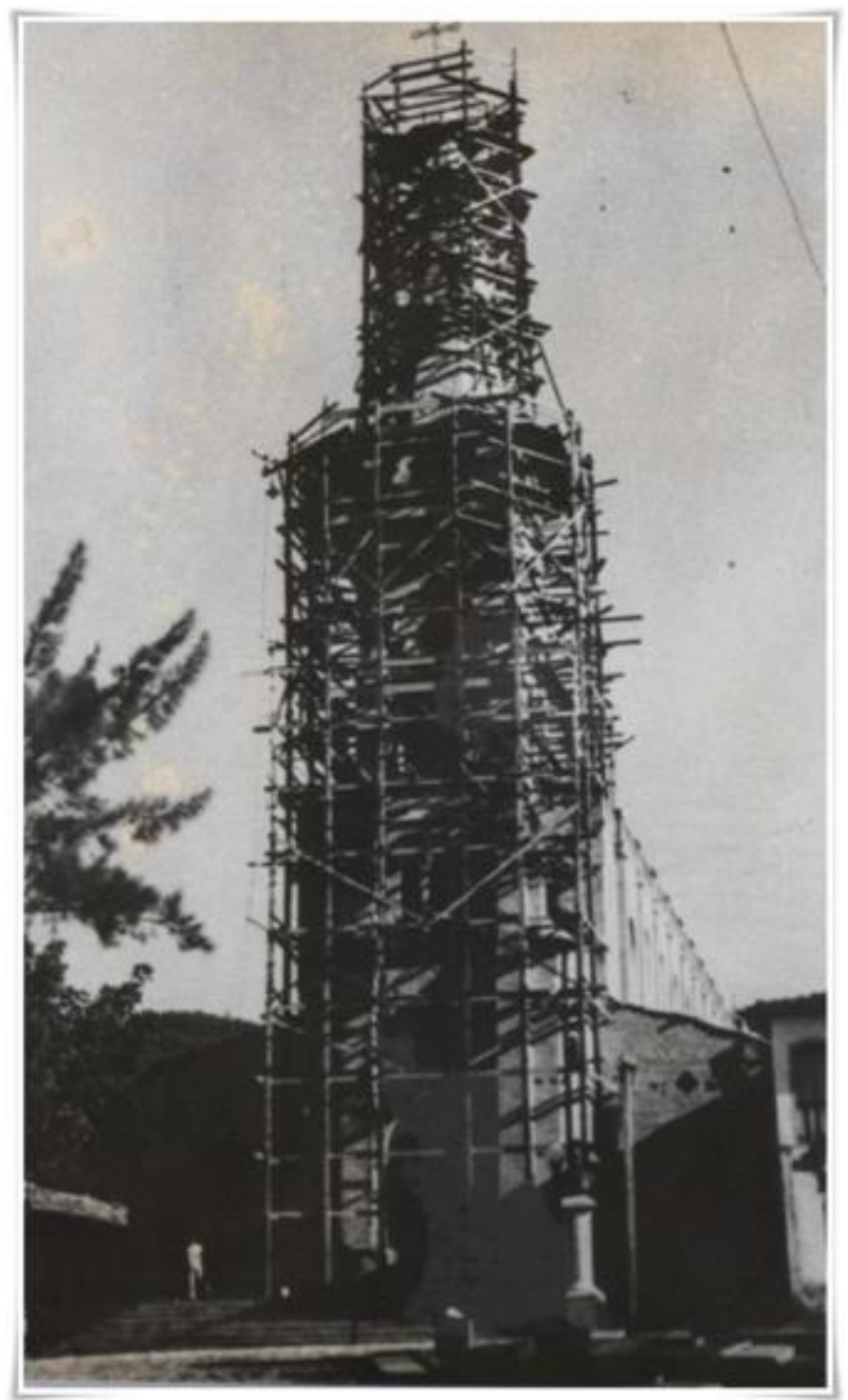

Fig. 05: Construção da torre da Igreja de Nossa Senhora do Rosário em 1943. Arquivo de Elder Camargo de Passos.

Cidade de Goiás 29 de julho 1942. Exc. Sr. Prefeito. Nesta. Frei Alberto M. Bortolan, Superior dos Padres Dominicanos desta cidade, vem respeitosamente pedir a V. Exc. Cia uma subvenção de 5:000\$000 (cinco contos de reis) no orçamento de 1943 para auxiliar a conclusão da torre da Igreja do S. Rosário que já constitue magnífico adorno desta antiga capital e que está fadado a atestar aos posteros a fé o espírito empreendedor dos que mourejam esta formosa nesga do território goiano. $O$ Convento Dominicano auxiliado pela generosidade do povo goiano luta para levar a bom termo a pesada empresa que o império das circunstâncias a fez herdar dos Dominicanos franceses de tão gratas recordações para os goianos em geral. Certo de que V. Excia não hesitará em acrescentar mais este benefício aos muitos que já lhe deve ao povo desta querida cidade. Com alta estima e consideração. Frei Alberto M. Bortolan, Superior.

Exm. ${ }^{\circ}$ Sr. Prefeito Municipal: Cumpre-se informar V. Excia., obedecendo a seu respeitável despacho, que o orçamento organizado para vigorar no futuro exercício de 1943 orça a receita municipal em 471:500\$000 e fixa a 
despesa em 454:571\$6000, havendo, de conseguinte, um superávit de 16:928\$4000. Em se tratando de auxiliar a conclusão das obras da Igreja do Rosário desta cidade, magnífico templo - o mais artístico e suntuoso de todo o Estado - e que é um atestado vivo do espírito de renovação por que passa este município, penso que o pedido formulado pelo digno superior do Convento dos Dominicanos pode ser atendido, não só porque existe saldo orçamentário, como porque o auxilio em apreço constituiria um estimulo a novas iniciativas que visem ao embelezamento da nossa terra. Prefeitura Municipal de Goiaz, 8 de agosto de 1942. J. Ribeiro - Contabilista ${ }^{11}$.

Os documentos anexados são representações dos registros que ficaram para a posteridade acerca da demolição da anterior capela. A austeridade e engajamento sentidos no documento são indícios da tão "necessária" construção de um "magnífico" templo religioso, representante da modernidade na cidade. A nova igreja foi edificada em fases, sendo a última concluída em 1943, para tal empreendimento os dominicanos contaram com doações do então prefeito de Goiás, Zachel Alves de Castro e de doações do povo goiano. Tratando-se do problema central do trabalho, os registros são semelhantes às casas, portas e janelas do patrimônio, conforme descortinado por Chagas (2007, p. 217):

Por outra janela: do ponto de vista poético e museológico, tanto a presença quanto a ausência da porta, enquanto corpo patrimonial, podem ser criativas, produtivas e estimulantes. Pela presença ou pela ausência, pela preservação ou pela destruição, o que importa é que o patrimônio cultural corpo portal imaginário - é atravessado por múltiplas linhas de força e poder, por tradições, contradições, conflitos e resistências; nada nele é natural - mesmo se chamado de natural - tudo é mediação cultural. (CHAGAS, 2007, p. 217).

Apegados a esta "mediação cultural" ${ }^{12}$, nos permitimos, lançar elucubrações acerca das fontes e, as interpretamos, tanto as fontes escritas quanto as imagens, como "janelas e portas", capazes de oferecer meios para se problematizar silêncios na e da história, diretamente relacionados à memória e identidade negra em Goiás, levando em conta que os apagamentos

\footnotetext{
${ }^{11}$ Autuação de pedição $\mathrm{n}^{\circ}$ 696, feita pelo Frei Alberto M. Bortolan junto à prefeitura municipal da cidade de Goiás exigindo ajuda de custo para a conclusão da torre da Igreja de Nossa Senhora do Rosário em 1942.

${ }^{12}$ Compreendemos "mediação cultural", um elemento que se faz presente em todo o ambiente social, vez que este é regido por relações simbólicas e jogos de poder, conflitos e contradições, como bem explica Mario Chagas quando se refere ao campo museal que se mantém "em movimento, tanto quanto o domínio patrimonial. Esses dois terrenos que ora se casam, ora se divorciam, ora se interpenetram, ora se desconectam, constituem corpos em movimento. E como corpos eles também são instrumentos de mediação, espaços de negociação de sentidos, portas (ou portais) que ligam e desligam mundos, indivíduos e tempos diferentes. O que está em jogo nos museus e também no domínio do patrimônio cultural é memória, esquecimento, resistência e poder, perigo e valor, múltiplos significados e funções, silêncio e fala, destruição e preservação. E por tudo isso interessa compreendê-los em sua dinâmica social e interessa compreender o que se pode fazer com eles, contra eles, apesar e a partir deles.” (2007, p. 222).
} 
perfilaram a demolição, construção e o novo nome da igreja, que de "Nossa Senhora do Rosário dos Pretos" passou a se chamar "Nossa Senhora do Rosário". A empreitada de construir outro templo e "modernizar" a arquitetura vilaboense não tentou apenas apagar as lembranças da cultura negra, mas sim de eliminá-la total e completamente do cenário histórico nos Sertões de Goiás.

\section{As veredas da história: itinerários culturais de uma cidade monumento}

Apegado às memórias de antanho, Bartolomeu Bueno da Silva Filho, o anhanguera ${ }^{13}$, enveredou-se pelos Sertões de Goiás na esperança de encontrar nestas paragens o ouro com o qual seu pai sonhara anos antes. Uma vez trilhado os mesmos caminhos de seu pai, em meados do século XVIII, após alcançar as margens do Rio Vermelho, Bartolomeu solicitou que procurassem "umas capoeiras em que seu pai plantara roça havia 40 anos". (BERTRAN, 2010, p. 48). Identificadas no "fim de sete dias (...), mudaram logo o arranchamento e roçando o lugar das casas de Manoel Pires Neves, deram com vestígios certos de que ali houve ranchos antigamente". (2010, p. 48).

Alcançado o provável lugar do "El dourado" no coração do Brasil, faltava apenas uma última prova que viesse confirmar os testemunhos de outrora, então logo examinaram o Rio "no lugar em que se fez a ponte da Lapa e deram por bem empregados os trabalhos passados com as mostras de ouro que viram e sucessivamente foram descobrindo pelo Rio acima". (2010, p. 48). Testificada a existência de ouro, a bandeira de Bartolomeu fixou-se na região do futuro Arraial de Sant'Anna, sede da Capitania de Goiás, este evento tornou "necessário estabelecer modo de Governo" (2010, p. 48). Anos depois, após ascender à categoria de Vila, os Sertões de Goiás receberam intenso fluxo migratório, caracterizando o lugar como importante centro urbano mineralógico e assinalado por uma sociedade composta de homens brancos e escravos.

Conforme Bertran (2010) em fins do século XVIII quando o ouro de aluvião já se esgotara e a mineração havia sido substituída pela agricultura de subsistência a "escravaria existente em Goiás na época atingira umas 40.000 pessoas" (2010, p. 22), dados estes corroborados por Karasch (2000) ao esclarecer que quase 1 milhão de negros africanos foram

\footnotetext{
${ }^{13}$ Cf. TAMASO, 2007. Verificar capítulo II - A narrativa mítica e a perda originária: ouro e índios. Neste capítulo a autora lança elucubrações acerca das construções mitológicas na história e nas identidades goianas.
} 
apartados no Valongo ${ }^{14}$, Rio de Janeiro, escravizados e posteriormente vieram (uma porcentagem significativa) a passos largos trabalhar nas margens do Rio Vermelho. As palavras de Karasch (2000) e sua experiência enquanto historiadora atuante no campo de estudo relacionado ao tráfico negro e ao cotidiano escravo em terras brasílicas esclareceu dúvidas quanto à constância com que foi utilizada a mão de obra escrava em Vila Boa de Goiás no ciclo aurífero do oitocentos. Como bem parafraseia, os "escravos cariocas há muito observavam os comboios de negros caminhando para o interior" (KARASCH, 2000, p. 93) a fim de trabalharem nas minas de ouro e diamantes. Uma vez assentados nas Capitanias de Minas, Mato Grosso e Goiás estes escravos traficados e/ou comercializados entre diversas regiões do país ${ }^{15}$ auxiliaram na construção de sociedades coloniais no interior do Brasil, no entanto se agruparam e foram representados como comunidades obtusas à cultura branqueada dos trópicos, que vieram ao encontro de lavores grosseiros e pesados, como a empreitada incessante das bandeiras pelo metal fulvo de valor inestimável. Depois de longa jornada através do Atlântico e pelo interior do Brasil os negros escravizados receberam a educação doutrinária do catecismo "com o objetivo de começar o processo de privar os africanos de sua cultura, os negociantes contratavam um instrutor para ensinar a eles sua nova religião, o catolicismo romano" (2000, p. 81), todavia não houve o apagamento total da cultura africana, como lembrado por Karasch (2000), pelo fato de os negociantes temerem a "doença mental" ou a "nostalgia", então os escravos eram estimulados com pimenta, gengibre, tabaco, tapas, socos, surras com chicote ou eram incentivados "a dançar e cantar a música de suas terras natais. Assim, o som de tambores e palmas e das canções africanas enquanto os escravos dançavam contribuía para o andamento da atmosfera do Valongo”. (2000, p. 80).

$\mathrm{O}$ esforço dos comerciantes de escravos em evitar a perca de seus investimentos promoveu o processo de sincretismo cultural e religioso por parte das comunidades negras que, construíram no Brasil culturas próprias marcadas pela exclusão, inferiorização e sonegação dos direitos de participação nas práticas e crenças da sociedade branca. Incluídos na filosofia católica, mas excluídos do direito de culto em irmandades brancas, os escravos construíram suas próprias comunidades e crenças, que funcionaram como forma de resistência. Nestes moldes a simples conversão ao catolicismo não significou o recalque de suas culturas originárias, mas funcionou como uma possibilidade para reunir dinheiro capaz

\footnotetext{
${ }^{14} \mathrm{Cf}$. KARASCH, 2000. "Na origem, Valongo era o nome da rua onde se localizavam as casas usadas como depósito dos africanos até serem vendidos para negociantes ou particulares (...) o Valongo era uma das áreas mais frequentadas do Rio (...)". (KARASCH, p. 75).

${ }^{15}$ Conforme Karasch (2000) e Loiola (2010) os escravos em Goiás não vieram diretamente do continente africano, mas de outras regiões do Brasil.
} 
de cobrir os custos do sepultamento de seus mortos em terreno consagrado, rezas para suas $\operatorname{almas}^{16}$, compra da alforria e adquirir "liberdade relativa para manter rituais afro-brasileiros". (2000, p. 348). Karasch propõem em suas palavras um processo de economia simbólica ${ }^{17}$ mantida pelos negros escravos no interior de suas organizações religiosas.

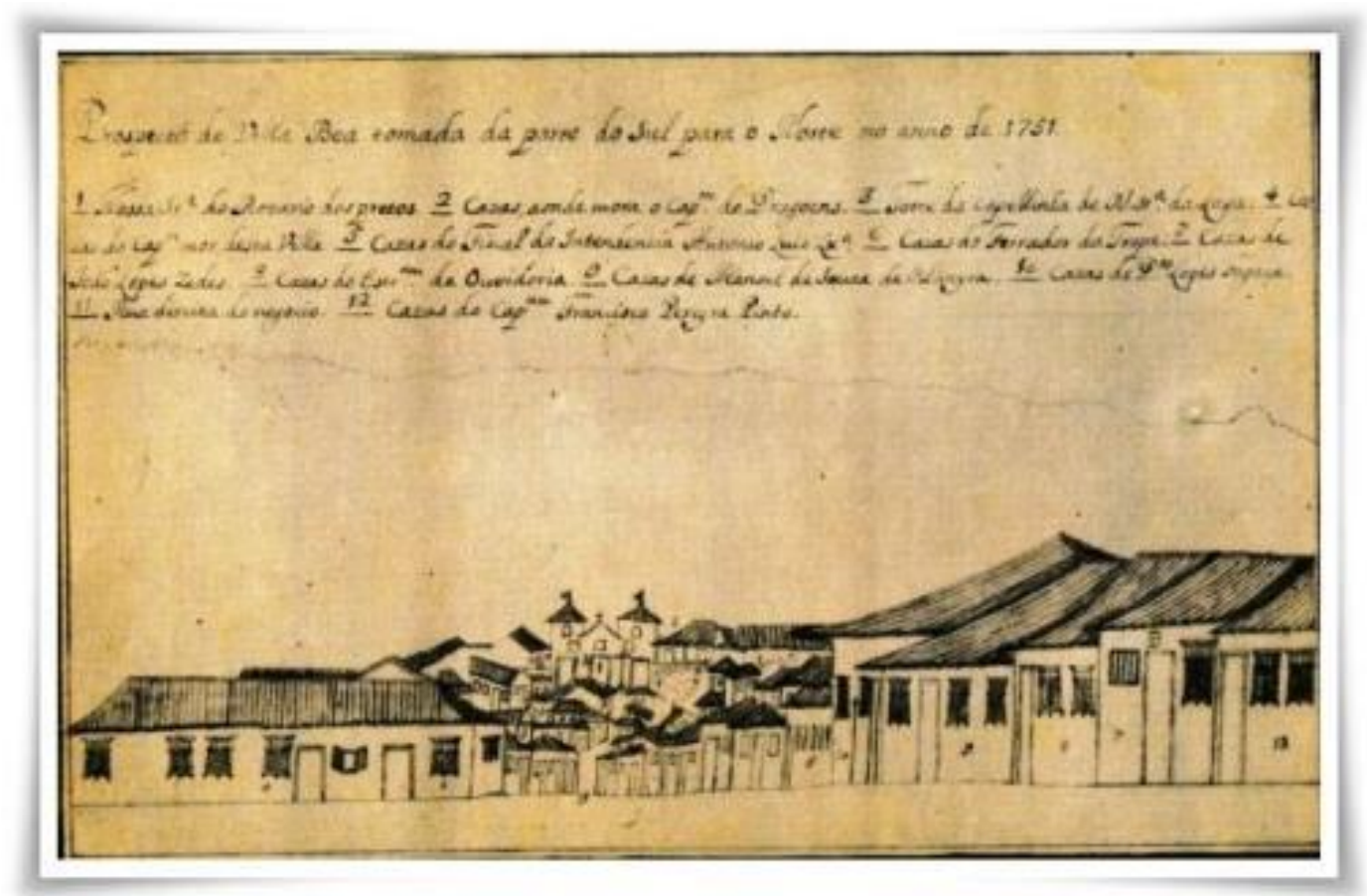

Fig. 06: Prospecto de Vila Boa tomada da parte do sul para o norte no anno de 1751. Original pertencente à Casa da Insua. Portugal, 1751. (GOULART, 2000, p. 235).

Nas veredas da pesquisa bibliográfica e em acervos documentais, foram colhidos espaços de experiência que proporcionaram a criação de horizontes de expectativas capazes de criar representações explicativas das comunidades negras enquanto participantes da construção identitária e cultural brasileira e nos Sertões de Goiás. Todavia por se tratar de questões muito amplas, este exercício se limitou ao recorte teórico e metodológico da problematização dos silêncios históricos voluntários ou não, desta participação desenterrada graças à existência de rastros resistentes à aguarrás do tempo e na ausência de "lugares de memória" enquanto incentivadores da produção de enigmas e palimpsestos incrustados no patrimônio cultural de Goiás.

\footnotetext{
${ }^{16}$ Conforme Karasch (2000) nas páginas 347 e 348, a reunião de negros em uma comunidade religiosa representada em Irmandades, como a de Nossa Senhora do Rosário dos Pretos, não significava simples entrega ou conversão à crença própria do catolicismo popular brasileiro, mas uma forma de resistir contra os esforços brancos em apagar os traços de suas culturas africanas.

${ }^{17}$ Cf. BOURDIEU, 2007. Neste trabalho o autor esclarece as noções de economia simbólica percebidas nos meandros das relações culturais na sociedade.
} 


\section{Patrimônio, identidade e poder: no encalço dos vazios historiográficos}

A avaliação da problemática do patrimônio cultural por meio das representações da história, das identidades e das relações étnico - raciais ${ }^{18}$ em Goiás tem como gancho de debate os palimpsestos deixados pela corrida do tempo e se tornou sugestiva enquanto exercício problematizador dos silêncios historiográficos e recalques da memória no momento em que tentamos esclarecer por meio da apropriação de experiências, um passado incômodo, pouco argumentado, mas que se faz presente no habitus vilaboense e em suas representações identitárias, monumentos e na cultura. Questionar o patrimônio em Goiás proporcionou a sensação de que ele se liga ao território e à memória, que operam um e outro como vetores “da identidade (...) uma identidade que se confessa inquieta, arriscando-se de se apagar ou já amplamente esquecida, obliterada, reprimida: de uma identidade em busca dela mesma, a exumar a 'bricoler', e mesmo a inventar". (HARTOG, 2006, p. 266).

No debate das propostas e objetivos a observação patrimonial tentou por meio de "um convite à anamnese coletiva" (2006, p. 266), ir "além da pedra e do cal, na busca de uma concepção ampla e mais democrática do patrimônio cultural” (FONSECA, 2003), alcançando possivelmente as relações de poder emanadas do patrimônio e esbarrando no "problema do conflito de interesses" (MESENES, 1992, p. 192) e identidades caracterizados pelas relações subjetivas "dos indivíduos (em sociedade) com espaços, estruturas, objetos (...) para indicar que o homem, ser social, é incapaz de viver externamente a esse duplo eixo do espaço/tempo" (1992, p. 193), o que elucida a idéia de que o patrimônio enquanto representação da história é a "memória que não deixa de brincar com a identidade, embora mantenha um pacto com ela". (JEUDY, 1990, p. 19).

O exercício norteado pela observação patrimonial e alicerçado em debates teóricos e metodológicos acerca da historiografia pós-estruturalista sugeriu a existência de fendas na

\footnotetext{
${ }^{18}$ Entendemos relações étnico - raciais pelo viés sugerido por Antonio Sérgio Alfredo Guimarães (2001) na ocasião de sua crítica do conceito de "democracia racial" evidenciado em alguns trabalhos de Gilberto Freyre e trazido para a discussão no campo da intelectualidade brasileira nos anos 1940 por Roger Bastide. Buscamos maiores compreensões em Dalmir Francisco (1997) no momento em que sugeriu ser o campo étnico e racial brasileiro o resultado de relações de poder onde se encontra em disputa a construção das identidades brasileiras. De acordo com o estudioso historicamente, "houve a necessidade de combater o racismo, luta que implicou em criar uma contra-ideologia, em contradizer o que os racistas brancos (e não-brancos) afirmam negativamente sobre os negros e das limitações que são impostas aos negros. Tratou-se, pois, de um processo de auto-defesa, de um racismo anti-racista, de uma contra-ideologia/racista necessária para o estabelecimento e para o própria vitalidade de luta (ir ao combate concitando o outro à luta). Mas, neste fim de século, o racismo anti-racista (legítima defesa) e o apelo à identidade racial tornaram-se contra-ideologias anacrônicas e eticamente indefensáveis." (1997, p. 192-193).
} 
história regional necessárias de ser avaliadas pelo fato de aparecerem "sombras engendradas pelo desaparecimento" (1990, p. 27) de lugares de memórias, de maiores preocupações no campo da construção da identidade, que deixou de ser "plenamente unificada, completa, segura e coerente" (HALL, 2006, p. 13), mas graças à "multiplicação dos sistemas de significação e representação cultural se multiplicou" (2006, p. 13) assumindo o caráter de pluralidade e permitiu-se ligar ao patrimônio conforme ressaltado por Hall (2006, p. 70 - 71):

$O$ que é importante para nosso argumento quanto ao impacto da globalização sobre a identidade é que o tempo e o espaço são também as coordenadas básicas de todos os sistemas de representação. Todo meio de representação - escrita, pintura, desenho, fotografia, simbolização através da arte ou dos sistemas de telecomunicação - deve traduzir seu objeto em dimensões espaciais e temporais. (...). Todas as identidades estão localizadas no espaço e no tempo simbólicos. Elas têm aquilo que Edward Said chama de suas "geografias imaginárias" (Said, 1990): suas "paisagens" características, seu senso de "lugar", de "casa/lar", ou heimat, bem como suas localizações no tempo - nas tradições inventadas que ligam passado e presente, em mitos de origem que projetam o presente de volta ao passado, em narrativas de nação que conectam o indivíduo a eventos históricos nacionais mais amplos, mais importantes. (HALL, 2006, p. $70-71)$.

O relacionamento firmado entre memória e espaço (Cf. HALBWACHS, 2006), foi conferido a partir da corrida de memórias e lembranças inquietas quanto à necessidade de proteger as representações patrimoniais em Goiás, pelo fato de serem "as garantias de nossa identidade, pessoal, local, nacional, humana" (CHOAY, 2001, p. 181), por significar por um lado a perspectiva de guarda monumental, articulada em "torno de marcos usuais (a catedral, a hospedaria da cidade), por outro cotidiana, vivida nos percursos de ruas e praças" (JEUDY, 1990, p. 17) e finalmente pelo fenômeno do presentismo e do nascimento de novos regimes de historicidade por meio da detecção de fendas do passado visíveis em nosso presente e observadas por Hartog (2011, p. 15):

Outra fenda apareceu no presente por meados dos anos setenta, tão bombástica, mas já bem obcecada com predições: mostrou-se ansiosa acerca da questão da identidade, numa busca pelas raízes, uma ânsia de memória, preocupada com o "patrimônio", atormentada pela conservação de monumentos, de lugares antigos ou não tanto, a preservação da natureza. Ansiosa com a recuperação do que fora perdido, ou estava para ser perdido ou inquieto com o que fora "esquecido" (especialmente a memória da II Guerra Mundial). Pode-se constatar a verdadeira "explosão" dos monumentos do Holocausto nos anos recentes em vários países ou, na França, o impacto do filme "Le Chagrin et la Pitié" (1971) de M. Ophuls. Rememoração, conservação ampla, ou renovação e reabilitação nas 
políticas urbanas têm valido contra a simples modernização, desafiando a sua até então inquestionada evidência. (HARTOG, 2011, p. 16).

Em sua elucubração acerca do tempo, da história e de sua escrita, Hartog (2011) estabeleceu paralelos importantes com as expectativas e preocupações enunciadas e que se assemelharam muito às análises históricas pós estruturalistas que permitiram olhar conjuntos arquitetônicos antigos, e manifestações culturais, atribuindo-lhes as categorias de monumentos e patrimônios culturais representantes de ícones da memória coletiva, lugares de memória, lugares de esquecimento, recalque e apagamento, pelo fato de "não podermos falar de memória, articulando-a à identidade sem inseri-la num afrontamento de forças e sem levarmos em conta que a memória é, antes de mais nada, um instrumento de poder". (GONDAR, s/d p. 37).

Observado por meio da categoria de poder, o patrimônio em Goiás assumiu as características de um poder simbólico centralizado à concepção de campo lançado por Bourdieu (1990), pelo fato de sê-lo uma espécie de círculo cujo centro se encontra em toda a parte e em parte alguma. Conforme Bourdieu (1990) é preciso saber identificá-lo onde ele se deixa ver menos, onde ele é mais "completamente ignorado, portanto reconhecido: o poder simbólico é, com efeito, esse poder invisível e qual só pode ser exercido com a cumplicidade daqueles que não querem saber que lhe estão sujeitos ou mesmo que o exercem". (BOURDIEU, 1990, p. 07 - 08). Neste ponto lançamos a lume os questionamentos que nortearam a pesquisa referente à demolição e reconstrução da Igreja de Nossa Senhora do Rosário dos Pretos em Goiás em moldes europeus, o que garantiu a reafirmação da forte presença do catolicismo romano na cidade, e encobriu em brumas, as lembranças e a herança africana presente nas identidades vilaboenses pós modernas ${ }^{19}$. Metodologicamente não nos arriscamos em afirmações quanto às origens da construção identitária em Goiás e das questões afro descendentes, pelo fato de não deter em mãos fontes capazes de comprovar tais pretensões e por não haver espaço ou mesmo tempo para tal empreitada. Apegamo-nos à interrogação das identidades existentes, tentamos ligar a cultura negra a estas identidades, às noções de esquecimentos voluntários e involuntários, das memórias e de suas construções como sugerido por Gondar (s/d, p. $37-38$ ):

\footnotetext{
${ }^{19}$ Neste ponto fazemos referência à grande quantidade de manifestações culturais de matriz africana na cidade. Com o crescimento geográfico de Goiás, muitas manifestações foram empurradas para as periferias. Cotidianamente é possível identificar em Goiás muitos centros de religiosidades de matriz africana, grupos de capoeira e manifestações culturais que remontam as festividades africanas dos séculos passado. Infelizmente o trabalho não se alongará nestas discussões, pelo fato de não haver espaço e tempo, mas será repensado para futuras pesquisas e questionamentos. Os maiores exemplos de resistências das culturas de matriz africanas na cidade de Goiás são o Espaço Cultural Vila Esperança e a Escola Pluricultural OdÉ Kayadê. Cf. SILVA, 2008.
} 
(...) não devemos esquecer que a constituição de uma memória impõem operações de segregação, e que a manutenção e o exercício dessa memória exige que se mantenha a exclusão - sob a forma do recalcamento, dissimulação, interdição, repressão ou censura - daquilo que põem em xeque a imagem ou representação de si mesmo que se tenta preservar. Ou seja, a própria sociedade deseja ocultar tudo aquilo que pode revelar seus paradoxos, suas falhas, enfim, tudo aquilo que poderia comprometer a imagem - a ficção - que ela pretende fornecer sobre si mesma. Assim ela não apenas se 'esquece' destes elementos capazes de revelar sua alteridade consigo própria, como também se esquece deste esquecimento, e dos meios que utilizou ou utiliza para efetivá-lo. Em outras palavras: não esquecemos apenas os elementos segregados, mas o próprio fato de que houve uma segregação, e as maneiras pelas quais segregamos. (GONDAR, s/d, p. 37 $-38)$.

A máquina do esquecimento promoveu o apagamento de elementos importantes da história, no entanto antes de julgarmos este evento optamos por considerar as sugestões de Gondar (s/d) acerca da característica biangular que o esquecimento assumiu mediante uma construção histórica e nos itinerários da memória coletiva. Sabemos que o trabalho com memórias e lembranças estabelece relações de poder, pelo fato de serem manipuladas, então tentamos estabelecer uma relação de forças entre a memória e o fenômeno do esquecimento, na busca de uma desnaturalização deste esquecimento enquanto "tarefa essencial para pensarmos a constituição da memória" (GONDAR, s/d, p. 38).

Nos itinerários de produção da pesquisa lançamos dúvidas e inquietações quanto às possíveis relações de poder, identificadas na "construção da realidade que tende a estabelecer uma ordem gnoseológica: o sentido imediato do mundo (e em particular, do mundo social)" (BOURDIEU, 1990, p. 09), que por sua vez caracterizou o desaparecimento de registros e da inexistência de lugares de memória quando a relacionamos ao contexto vilaboense, onde a eficaz política de segregação racial e cultural acentuada pela "expulsão dos moradores mais pobres das áreas de intervenção, que recebem moradores mais abastados ou novas funções elitizadas". (JEUDY, 2005, p. 12), garantiram o recalque de fragmentos importantes da história e da cultural regional.

\section{Caminhos e métodos: considerações do infindável}

Iniciados na concepção de que os historiadores "enxergam diferente, pois vêem o mundo com olhos no passado" (PESAVENTO, 2005, p. 111) criamos expectativas diante das experiências históricas e, debruçados na concepção de que precisamos "ter filigranas no olhar para ver, no espaço transformado, destruído, desgastado, renovado pelo tempo, a cidade do 
passado" (PESAVENTO, 2005, p. 113), partimos em busca de respostas para perguntas sobre possíveis ocultamentos, segregações, dissimulações e censuras na história nos Sertões de Goiás. Enveredamo-nos pela aventura agradável das reminiscências confrontadas pelo presente, na tentativa de reinventar a história e refletir sobre questões ainda silenciadas.

O folhar dos livros, a análise dos documentos e a observação do patrimônio cultural em Goiás, criaram inquietações quanto aos esquecimentos, segregações das memórias nesta região e a presença negra enquanto participante das identidades culturais nesta sociedade, já que "Vila Boa de Goiás surgiu com a mineração no século XVIII e recebeu pessoas de diferentes partes do Brasil, da África e da Europa”. (TEDESCO, 2009, p. 01).

A heterogeneidade dos grupos sociais em Goiás garantiu a existência de conflitos identitários que fomentavam a "elaboração e reelaboração de práticas identitárias onde negros e brancos buscavam reforçar suas diferenças através da fragmentação da cidade em territórios". (2009, p. 01). A análise de documentos e a observação do patrimônio cultural fizeram com que aparecessem maiores questionamentos quanto à participação negra na construção das identidades culturais vilaboenses, para tanto lançamos mão deste exercício na intenção de repensar as memórias e lançar luzes para uma história das possibilidades.

\section{Referências bibliográficas}

ALBUQUERQUE JUNIOR, Durval Muniz de. História: a arte de inventar o passado. Ensaios de teoria da história. Bauru, SP: Edusc, 2007.

ALMEIDA, Adriano Alcântara. A Irmandade de Nossa Senhora do Rosário dos Pretos da Cidade de Goiás do século XIX. Monografia (Pós - Graduação latu sensu em História do Brasil). Goiás: Universidade Estadual de Goiás, 2001.

BELTRÃO, Jane Felipe; CAROSO, Carlos. Patrimônio, linguagens e memória social: problemas, estudos e visões no campo da antropologia. In: Antropologia e patrimônio cultural: diálogos e Desafios contemporâneos / Manuel Ferreira Lima Filho; Jane Felipe Beltrão; Cornelia Eckert. - Blumenau: Nova Letra, 2007.

Bellaigue, Mathilde. Memória, Espaço, Tempo, Poder. In: Revista Eletrônica do Programa de PósGraduação em Museologia e Patrimônio - PPG-PMUS. Rio de Janeiro: Unirio, 2009

BERTRAN, Paulo. Noticia geral da Capitania de Goiás em 1783. - Goiânia: ICBC, 2010.

BOURDIEU, Pierre. A economia das trocas simbólicas. São Paulo: Perspectiva, 2007. As regras da arte - Gênese e estrutura do campo literário. Rio de Janeiro: Companhia das letras, 1990. O poder simbólico. Rio de Janeiro: Editora Bertran, 1989.

CARVALHO, José Murilo de. Os bestializados - O Rio de Janeiro e a República que não foi.São Paulo: Companhia das letras, 1987. 
CHAGAS, Mário. Casas e portas da memória e do patrimônio. In: Revista Em Questão. Porto Alegre, 2007. . Memória política e política de memória. In: Memória e patrimônio: ensaios contemporâneos / Regina Abreu; Mário Chagas (Org.). - Rio de Janeiro: DP\&A, 2003.

CHARTIER, Roger. A história cultural: entre práticas e representações. Rio de Janeiro: Bertrand, 1987.

CHOAY, Françoise. A alegoria do patrimônio. Tradução de Luciano Vieira Machado. - São Paulo: estação Liberdade: Editora UNESP, 2000.

COELHO, Gustavo Neiva. A formação do espaço urbano nas vilas do ouro: o caso de Vila Boa. Dissertação (Mestrado em História). Goiânia: Universidade Federal de Goiás, 1997.

COUTINHO, Graça. Mosaico da memória. In: Revista Tempo Brasileiro. - Rio de Janeiro: Tempo Brasileiro, 2001 .

COLLINS, John F. A razão barroca do patrimônio baiano: contos de tesouro e histórias de ossadas no Centro Histórico de Salvador. In: Revista de Antropologia, São Paulo: USP, 2008.

CURADO, S. Fleury. Memórias Históricas. Goiânia: Estado de Goiás - Fac. Similar, 1989.

ELHAJJI, Mohammed. Culturas em trânsito : patrimônio imaterial, memória e espaço. In: Revista Museologia e Patrimônio, 2010

FONSECA, Maria Cecília Londres. Para além da pedra e cal: por uma concepção ampla de patrimônio cultural. In: Memória e patrimônio: ensaios contemporâneos/Regina Abreu; Mário Chagas (Org.). - Rio de Janeiro: DP\&A, 2003.

FRANCISCO, Dalmir. Negro, etnia, cultura e democracia. In: Revista do Patrimônio Histórico e Artístico Nacional, $\mathrm{n}^{\circ}$ 25, 1997.

GALLAIS, P. Estevão Maria. O apostolo do Araguaia - Frei Gil Vilanova missionário dominicano. Prelazia de Conceição do Araguaia, 1942.

GAGNEBIN, Jeanne Marie. Lembrar escrever esquecer. São Paulo: Ed.34, 2006.

GONDAR, Jô. Lembrar e esquecer: desejo de memória. In: Memória e espaço / Icléia Thiesen Magalhães Costa; Jô Gondar (Org.). - Rio de Janeiro: 7 Letras, s/d.

GONÇALVES, José Reginaldo Santos. O patrimônio como categoria de pensamento. In: Memória e patrimônio: ensaios contemporâneos / Regina Abreu; Mário Chagas (Org.). - Rio de Janeiro: DP\&A, 2003.

GIOVANAZ, Marlise. Pedras e emoções: os percursos do patrimônio. In: Revista Em Questão. Porto Alegre, 2007.

GUIMARÃES, Antonio Sérgio A. Democracia racial: o ideal, o pacto e o mito. In: Novos Estudos, $\mathrm{n}^{\circ}$ 61, 2001.

HALBWACHS, Maurice. A memória coletiva; tradução de Beatriz Sidou. São Paulo:

Centauro, 2006.

HALL, Stuart. A identidade cultural na pós - modernidade. Tradução de Tomaz Tadeu da Silva, Guacira Lopes Louro - Rio de Janeiro: DP\&A, 2006.

HARTOG, Françoise. Tempo e patrimônio. In: Varia história. Belo Horizonte, 2006.

HARTOG, Françoise. Regime de Historicidade - Tempo, História e a escrita da história: a Ordem do tempo. In:, 2011.

JEUDY, Henri Pierre. Memórias do social. Rio de Janeiro: Forense Universitária, 1990.

. Espelho das cidades. Tradução Rejane Janowitzer - Rio de Janeiro: Casa da Palavra, 2005. 
KARASCH, Mary C. A vida dos escravos no Rio de Janeiro (1808 - 1850). Tradução Pedro Maia Soares - São Paulo: Companhia das Letras, 2000.

LACERDA, Regina. Vila Boa. Goiânia: Oriente, 1977.

LE GOFF, Jacques. História e memória. Campinas, SP: Ed. da UNICAMP, 1990.

LOIOLA, Maria Lenke. Trajetórias para a liberdade: escravos e libertos na capitania de Goiás. - Goiânia: Editora UFG, 2009.

MAIOLINO, Claudio Forte. A arquitetura religiosa neogótica em Curitiba entre os anos de 1880 e 1930. Dissertação (Mestrado em Arquitetura) - Rio Grande do Sul: Universidade Federal do Rio Grande do Sul, 2007.

MENESES, Ulpiano Bezerra. O patrimônio cultural entre o público e o privado. In: $O$ direito à memória patrimônio histórico e cidadania. São Paulo: Departamento do Patrimônio Histórico, 1992.

MORAES, Cristina de Cássia Pereira. Do corpo místico de Cristo: irmandades e confrarias na Capitania de Goiás (1736 - 1808). 2005. Tese (Doutorado em História) - Lisboa: Universidade Nova de Lisboa, 2005.

NORA, Pierre. Entre memória e história: a problemática dos lugares. In: Projeto de história-Revista do Programa de Estudos Pós-Graduação em História e do Departamento de História da PUC-SP. (Pontifícia Universidade Católica de São Paulo). São Paulo, SP-Brasil, 1993.

OLIVEN, Ruben George. Patrimônio intangível: considerações iniciais. In: Memória e patrimônio: ensaios contemporâneos / Regina Abreu; Mário Chagas (Org.). - Rio de Janeiro: DP\&A, 2003.

PESAVENTO, Sandra Jatay. Com os olhos no passado: a cidade como palimpsesto. In: Narrativas da pósmodernidade na pesquisa histórica/ Sandra de Cássia Araújo Pelegrine, Silvia Helena Zanirato (organizadoras) Maringá: Eduem, 2005.

REIS, Nestor Goulart. Imagens de Vilas e Cidades do Brasil Colonial. São Paulo: Editora da Universidade de São Paulo: Imprensa Oficial do Oficina do Estado: Fapesp, 2000.

ROCHA, Ana Luiza Carvalho da Rocha. A cidade: sede de sentidos. In: Antropologia e patrimônio cultural: diálogos e Desafios contemporâneos / Manuel Ferreira Lima Filho; Jane Felipe Beltrão; Cornelia Eckert. Blumenau: Nova Letra, 2007.

ROTMAN, Mónica; CASTELLS, Alicia Norma González. Patrimônio e cultura: processos de politização, mercantilização e construção de identidades. In: Antropologia e patrimônio cultural: diálogos e Desafios contemporâneos / Manuel Ferreira Lima Filho; Jane Felipe Beltrão; Cornelia Eckert. - Blumenau: Nova Letra, 2007.

SAMUEL, Raphael. Paisagens Oníricas. In: Projeto de história-Revista do Programa de Estudos Pós-Graduação em História e do Departamento de História da PUC-SP. (Pontifícia Universidade Católica de São Paulo). São Paulo, SP-Brasil, 2000.

. Escopofilia. In: Projeto de história-Revista do Programa de Estudos Pós-Graduação em História e do Departamento de História da PUC-SP. (Pontifícia Universidade Católica de São Paulo). São Paulo, SP-Brasil, 1993.

SILVA, Mônica Martins da. A festa do divino - romanização, patrimônio e tradição em Pirenopólis (1890 1988). Goiânia: 2001.

SILVA, Flávia Cavalcante da Conceição. Escola Pluricultural Odé Kaiodê (2004-2007). Trabalho de conclusão de curso em História. Universidade Estadual de Goiás: Jussara, 2008.

TAMASO, Izabela. Em nome do patrimônio: representações e apropriações da cultura na Cidade de Goiás. Tese (Doutorado em Antropologia). Brasília: Universidade de Brasília, 2007. 
TEDESCO, Gislaine Valerio de Lima. Do Lado de Lá e do Lado de Cá de Vila Boa de Goiás: Fronteiras Culturais e Espaciais entre negros e brancos no século XIX. In: $4^{\circ}$ Encontro Escravidão e Liberdade no Brasil Meridional. Curitiba, 2009.

TELES, José Mendonça. Vida e obra de Silva e Souza. Goiânia: Ed. Da UFG, 1998.

VELHO, Gilberto. Patrimônio, negociação e conflito. In: Antropologia e patrimônio cultural: diálogos e Desafios contemporâneos / Manuel Ferreira Lima Filho; Jane Felipe Beltrão; Cornelia Eckert. - Blumenau: Nova Letra, 2007. 